\title{
HUBUNGAN E-BANKING DALAM MENINGKATKAN CITRA PRODUK TABUNGAN IB PLUS DAN KARTU BNI SYARIAH
}

\author{
Prapti Daliyanik \\ DPP Ikatan Ahli Ekonomi Islam Indonesia (IAEI)
}

\begin{abstract}
The Correlation of E-Banking in The Way to Increase the Saving iB Plus Product and BNI Syariah Card Images. The aim of this research is to analyze the correlation between e-banking to the images increasing of iB plus saving product and BNI Syariah card. And also to the customer's perception of ebanking services on iB plus saving product and BNI Syariah card. The analysis method that used in this research is correlation analysis. The correlation between e-banking service on image product increasing is about 0,583 or 58,3\%. It means that between e-banking services (based on customer's perception) and image product increasing of $i B$ plus product and BNI Syariah card has an average correlation.
\end{abstract}

Keywords: e-banking, product image, correlation

\begin{abstract}
Abstrak. Hubungan E-Banking Dalam Meningkatkan Citra Produk Tabungan iB Plus dan Kartu BNI Syariah. Penelitian ini bertujuan untuk menganalisis adanya hubungan e-banking pada peningkatan citra produk tabungan iB Plus dan BNI Syariah Card. Serta persepsi nasabah terhadap layanan e-banking pada produk tabungan iB Plus dan BNI Syariah Card. Teknik analisis yang dipergunakan ialah teknik analisis korelasi. Besarnya hubungan variabel layanan e-banking (Persepsi Nasabah) terhadap variabel Peningkatan Citra Produk iB Plus dan BNI Syariah Card adalah 0,583 atau 58,3\%. Hal ini berarti bahwa hubungan antara variabel Layanan E-Banking (persepsi nasabah) terhadap variabel Peningkatan Citra Produk iB Plus dan BNI Syariah Card adalah berukuran sedang.
\end{abstract}

Kata Kunci: e-banking, citra produk, korelasi 


\section{PENDAHULUAN}

Perkembangan perbankan syariah di Indonesia saat ini merupakan suatu perwujudan dari permintaan masyarakat yang membutuhkan suatu sistem perbankan yang sehat, juga memenuhi prinsip-prinsip syariah. Namun seiring dengan pesatnya perkembangan perbankan syariah di Indonesia, maka harus diiringi pula oleh sarana teknologi sebagai pendukung majunya perbankan syariah di Indonesia. Dan kini hampir di setiap bank di Indonesia baik bank pemerintah maupun swasta, dan bank konvensional maupun syariah telah menggunakan jasa teknologi untuk mempermudah segala transaksinya atau untuk memasarkan produk-produknya, yang dalam dunia perbankan di kenal dengan istilah E-Banking (Electronic banking).

E-Banking dalam lembaga perbankan syariah dimaksudkan untuk mempermudah segala bentuk transaksi perbankan dan juga merupakan sebagai salah satu cara untuk menarik minat para nasabah untuk menggunakan produk tabungan yang dilengkapi dengan layanan e-banking. E-Banking juga memberikan kemudahan dan kenyamanan kepada nasabahnya dengan fasilitas pelayanan pembayaran melalui saluran elektronik, Seperti melalui transfer rekening dan auto debet. Cara ini cukup efektif dan efisien mengingat masyarakat semakin disibukkan dengan segala aktivitasnya.

Contohnya seperti BNI Syariah yang juga memiliki layanan $e$ banking, dengan layanan inilah nasabah bisa menggunakan berbagai fasilitas seperti BNI ATM, BNI SMS Banking, BNI Internet Banking, BNI Phone Plus, dan BNI Mobile. BNI Syariah telah menanamkan investasi sarana dan teknologi informasi berupa e-banking dalam upaya memasarkan produknya dan sebagai penunjang transaksi perbankan, sehingga diharapan penghimpunan dana masyarakat dapat meningkat.

BNI Syariah juga memiliki produk Tabungan iB Plus yaitu tabungan yang dikelola berdasarkan prinsip Mudharabah Mutlaqah. Dengan prinsip ini tabungan nasabah akan diinvetasikan secara produktif dalam investasi yang halal sesuai prinsip syariah, dan keuntungan dari investasi akan dibagihasilkan antara nasabah dan bank sesuai dengan nisbah yang disepakati diawal pembukaan tabungan iB Plus. Tabungan iB Plus memiliki manfaat dan 
keunggulan seperti kemudahan setor dan tarik on-line real time di seluruh kantor cabang BNI, mendapatkan BNI Syariah Card yang dapat dimanfaatkan sebagai kartu debet dan kartu ATM, mendapatkan fasilitas layanan e-banking (BNI Phone Plus, SMS Banking, Internet Banking, dan Mobile Banking), serta masih banyak manfaat serta keunggulan lainnya.

Hansory menyatakan bahwasanya e-banking dalam dunia perbankan termasuk perbankan syariah merupakan sarana unggulan tersendiri bagi pihak bank dalam memasarkan produk-produk tabungannya, seperti contoh bank X menawarkan produk tabungan yang tidak dilengkapi dengan layanan e-banking, sedangkan pihak BNI Syariah menawarkan produk tabungan yang dilengkapi dengan layanan $e$ - banking. Maka akan lebih mudah bagi pihak BNI Syariah dalam memikat para nasabah untuk menggunakan produk tabungan yang dilengkapi dengan e-banking dibanding dengan produk yang tidak dilengkapi e-banking. Karena menurut pihak bank saat ini masyarakat menginginkan layanan yang dapat menghemat waktu dan biaya.

Zakiah juga menyatakan bahwasanya e-banking akan lebih mempermudah segala bentuk transaksi yang dilakukan antara pihak bank dengan nasabah. Selain itu mempermudah pihak bank khususnya customer service dan divisi pemasaran dalam menawarkan produk tabungan, seperti Tabungan iB Plus dan BNI Syariah Card yang dilengkapi dengan layanan $e$ banking. Dengan demikian menurut Zakiah e-banking bagi BNI Syariah merupakan sarana dalam menunjang transaksi dan dalam meningkatkan citra produk tabungan.

Al-Mubarak (2008) membahas mengenai peran dan fungsi internet banking terhadap transaski perbankan syariah kemudian cara mengopersionalisasikan transaksi melalui internet banking, serta membahas mengenai kelebihan dan kekurangan dalam melakukan transaksi melalui internet banking. Adapun obyek penelitiannya adalah PT. BNI Syariah Cabang Jakarta Selatan, dan metode penelitian yang digunakannya adalah kualitatif yang berbentuk deskriptif analitis dengan cara melakukan wawancara terhadap pemimpin bidang operasional.

Rini Andriani (2009) membahas mengenai e-banking sebagai sarana 
pendukung pemasaran produk asuransi syariah dan keuntungan yang dihasilkan e-banking bagi perusahaan asuransi syariah. Adapun obyek penelitiannya adalah PT. BNI Life Insurance, dan metode penelitian yang digunakan adalah kualitatif berbentuk analisis deskriptif dengan cara melakukan wawancara terhadap pihak-pihak yang bersangkutan.

Fitria Hasanah (2010) membahas mengenai persentase respon nasabah terhadap transaksi melalui internet banking dan keuntungan yang diperoleh para nasabah dalam melakukan transaksi melalui e-banking. Adapun obyek penelitiannya adalah nasabah tabungan pada PT. BNI Syariah Cabang Jakarta Selatan, dengan menggunakan metode penelitian yaitu kuantitatif berbentuk riset deskriptif dengan cara menyebarkan kuesioner kepada seluruh nasabah tabungan BNI Syariah.

Salah satu produk BNI Syariah Cabang Jakarta Selatan yang berbentuk tabungan adalah tabungan iB Plus yang disertai dengan BNI Syariah Card. Dan untuk memenuhi kebutuhan para nasabah, maka pihak bank menciptakan berbagai layanan yang menggunakan jasa e-banking, seperti BNI Internet Banking, BNI ATM, BNI SMS Banking, BNI PhonePlus, BNI Mobile. Layanan ebanking ini dimaksudkan untuk mempermudah segala bentuk transaksi yang di lakukan antara bank dengan nasabah.

Bank menyediakan layanan Electronic Banking atau e-Banking untuk memenuhi kebutuhan nasabah akan alternatif media untuk melakukan transaksi perbankan. Dengan Electronic Banking, nasabah tidak perlu lagi membuang waktu untuk antri di kantor-kantor Bank atau ATM, karena saat ini banyak transaksi perbankan dapat dilakukan dimanapun, dan kapanpun dengan mudah dan praktis melalui jaringan elektronik, seperti internet, handphone, dan telepon.

Ruang lingkup e-banking juga tidak semata-mata hanya menyangkut transaksi online, namun juga meliputi berbagai aktivitas, seperti melakukan riset pasar, mengidentifikasi peluang dan mitra bisnis, menjalin relasi dengan pelanggan dan pemasok, serta melakukan perancangan produk bersama mitra bisnis.Maka E-Banking dalam perusahaan merupakan suatu sarana transaksi bisnis ekonomi suatu perusahaan dengan perusahaan lain atau perusahaan 
dengan individu melalui saluran elektronik. Fasilitas e-banking yang berbasis teknologi ini memberikan manfaat bagi para pelaku ekonomi yaitu perusahaan dapat memasarkan produk yang dihasilkan dengan biaya distribusi yang rendah, sedangkan bagi nasabah memperoleh layanan transaksi bisnis yang aman, cepat, dan efektif dalam pemenuhan kebutuhan finansial

\section{METODE}

Populasi adalah totalitas dari semua objek atau individu yang memiliki karekteristik tertentu, jelas dan lengkap yang akan diteliti. Populasi yang digunakan penulis dalam skripsi ini adalah jumlah nasabah yang menggunakan e- banking di kantor cabang jakarta selatan berjumlah 293 nasabah, data ini diperoleh dari BNI Syariah Kantor Cabang Jakarta Selatan. Dalam penelitian ini sampel diambil dari sebagian populasi yang telah ditentukan, yaitu sebagian nasabah yang menggunakan layanan e-banking, baik laki-laki maupun perempuan. Teknik pengambilan sampel yang digunakan dalam penelitian ini adalah sistem random sampling, setiap populasi mempunyai kesempatan yang sama untuk dipilih sebagai sampel.

Dalam penelitian kuantitatif, analisis data merupakan kegiatan setelah data dari seluruh responden terkumpul. Kegiatan analisis data adalah mengelompokkan data berdasarkan variabel, dan jenis responden, mentabulasi data berdasarkan variabel dari seluruh responden, menyajikan data tiap variabel yang diteliti, melakukan perhitungan untuk menjawab rumusan masalah, dan melakukan perhitungan untuk menguji hipotesis yang telah diajukan.

Teknik analisis data yang akan dilakukan oleh penulis adalah metode statistik korelasi. Korelasi merupakan teknik analisis yang termasuk dalam salah satu teknik pengukuran asosiasi/hubungan (measures of association). Pengukuran asosiasi merupakan istilah umum yang mengacu pada sekelompok teknik dalam statistik bivariat yang digunakan untuk mengukur kekuatan hubungan antara dua variabel. koefisien korelasi menunjukkan nilai besaran antara $-1<0<1$, dimana apabila koefisien korelasi semakin mendekati nilai 0 maka hubungan antar variabel akan semakin lemah. Begitu pula sebaliknya apabila nilai besaran koefisien korelasi semakin mendekati \pm 1 , hal tersebut 
menunjukkan bahwa hubungan antar variabel akan semakin menguat.

Setelah mengetahui besarnya koefisien korelasi, maka harus menguji hipotesis nol. Jika sampel yang diambil merupakan sampel besar, maka signifikasi yang dihasilkan di bawah hipotesis nol dapat diuji dengan pengujian dua arah (tingkat signifikansi $=5 \%$ ) dengan menggunakan t-test

$$
t=\frac{r \sqrt{n-2}}{\sqrt{1-r^{2}}}
$$

Untuk menentukan apakah Ho ditolak atau diterima, akan diperbandingkan antara $\mathrm{t}$ hitung dengan $\mathrm{t}$ tabel. Apabila $\mathrm{t}$ hitung $>\mathrm{t}$ tabel maka Ho ditolak. Begitu pula apabila $\mathrm{t}$ hitung $<\mathrm{t}$ tabel maka $\mathrm{H}_{0}$ diterima. Sementara itu untuk mengetahui besarnya pengaruh variabel X terhadap variabel Y maka dipergunakan koefisien determinasi.

$$
\mathrm{R}^{2}=\mathrm{r}^{2} \times 100 \%
$$

Dimana :

$\mathrm{R}^{2}=$ koefisien determinasi

$\mathrm{r}=$ koefisien korelasi

Untuk keperluan interpretasi hasil perhitungan dari koefisien korelasi adalah:

$<0,20 \quad$ : hubungan sangat rendah

$0,20-0,40 \quad$ : hubungan yang rendah atau tidak erat

$0,40-0,70 \quad$ : hubungan yang sedang atau cukup erat

0,70-0,90 : hubungan yang erat atau kuat

$>0,90 \quad$ : hubungan yang sangat erat atau kuat sekali

\section{Pembahasan}

Berdasarkan hasil olahan yang telah dilakukan terdapat 169 responden, yang menggunakan internet banking sebesar 21,3\% atau berjumlah 36 orang, Mobile Banking sebesar 27,2\% atau berjumlah 46 orang, SMS Banking sebesar 37,9\% atau berjumlah 64 orang, Phone Plus sebesar 13,6\% atau berjumlah 23 orang. Dalam hal ini menunjukan bahwasanya kebanyakan responden atau nasabah lebih tertarik untuk menggunakan layanan SMS Banking karena menurut mereka lebih mudah persyaratannya dibandingkan dengan internet banking, mobile banking, atau phone plus. Ini terlihat dari 
banyaknya jumlah responden atau nasabah yang menggunakan layanan SMS Banking. Mayoritas responden menyatakan setuju untuk menggunakan layanan e-banking dengan persentase sebesar 58,6\%, sangat setuju $27,2 \%$, ragu 10,1\%, tidak setuju 4,1\% dan sangat tidak setuju 0. Ini berarti sebagian besar responden setuju berminat untuk menggunakan layanan $e$-banking.

Mayoritas responden menyatakan setuju bahwasanya layanan e-banking dapat lebih menghemat waktu dengan persentase sebesar 59,2\%, sangat setuju $24,9 \%$, ragu $16 \%$, tidak setuju $11 \%$ dan sangat tidak setuju 0 . Ini berarti sebagian besar responden setuju bahwasanya e-banking dapat lebih menghemat waktu. Selain itu, mayoritas responden menyatakan setuju mengerti atau memahami dalam mengikuti petunjuk yang disarankan bank untuk penggunaan layanan e-banking dengan persentase sebesar 60,9\%, sangat setuju $11,8 \%$, ragu $24,3 \%$, tidak setuju $3 \%$ dan sangat tidak setuju 0 . Ini berarti sebagian besar responden setuju bahwasanya mereka mengerti dalam mengikuti petunjuk yang disarankan bank untuk penggunaan $e$-banking, akan tetapi tidak sedikit responden yang menjawab ragu-ragu, ini berarti tidak seluruh responden mengerti atau memahami betul akan petunjuk yang disarankan oleh bank untuk penggunaan layanan e-banking. Kemudian, mayoritas responden menyatakan setuju bahwasanya tampilan fitur e-banking dikemas secara menarik, mudah dimengerti, dan diikuti dengan persentase sebesar 58,6\%, sangat setuju 16,6\%, ragu 22,5\%, tidak setuju 2,4\% dan sangat tidak setuju 0 . Ini berarti sebagian responden setuju bahwasanya tampilan fitur e-banking dikemas secara menarik, mudah dimengerti, dan diikuti oleh mereka, namun ada sebagian responden yang menjawab raguragu, ini berarti mereka ragu bahwa tampilan fitur e-banking menarik, mudah di mengerti, dan diikuti, karena menurut mereka terkadang fitur e-banking agak sulit untuk dimengerti.

Terkait dengan kualitas layanan e-banking, mayoritas responden menyatakan setuju bahwasanya dengan persentase sebesar 51,5\%, sangat setuju $17,8 \%$, ragu $29,6 \%$, tidak setuju $1,2 \%$ dan sangat tidak setuju 0 . Ini berarti sebagian besar responden setuju bahwasanya kualitas layanan $e$-banking sangat memuaskan, namun ada beberapa responden yang masih ragu- 
ragu mengenai kualitas layanan e-banking sangat memuaskan, karena terkadang mereka mengalami trouble loading dalam mengakses layanan $e$ banking. Jika dilihat berdasarkan data dan olahan data yang ada, rata-rata responden menjawab setuju, ragu-ragu, dan sangat setuju. Hal ini menggambarkan bahwasanya sejauh ini persepsi responden (nasabah) mengenai layanan e-banking itu bersifat positif atau dapat dikatakan baik, karena responden yang menjawab tidak setuju dan sangat tidak setuju terbilang sedikit atau jarang. Dalam hal ini, tidak sedikit responden (nasabah) yang menjawab ragu-ragu, ini berarti saat ini nasabah masih ragu-ragu terhadap layanan e-banking. Oleh karena itu pihak bank harus lebih meningkatkan kualitas layanan e-banking, sehingga para nasabah lebih merasa aman, nyaman, dan puas dalam menggunakan layanan e-banking tersebut, selain itu juga pihak bank harus lebih menanamkan keyakinkan kepada para nasabah bahwasanya dengan e-banking transaksi jauh lebih mudah, efektif, dan efisien. Dan kedepannya pihak bank harus lebih mensosialisasikan e-banking terhadap para masyarakat luas khususnya para nasabah yang belum menggunakan layanan e-banking.

Terkait dengan tabungan iB plus dan BNI Syariah Card, mayoritas responden menyatakan sangat setuju bahwasanya tabungan iB Plus dan BNI Syariah Card merupakan investasi yang halal dan sesuai dengan prinsip syariah dengan persentase sebesar $43,8 \%$, setuju $42 \%$, ragu $14,2 \%$, tidak setuju 0 dan sangat tidak setuju 0 . Ini berarti sebagian besar responden sangat setuju bahwasanya tabungan iB Plus dan BNI Syariah Card merupakan investasi yang halal dan sesuai dengan prinsip syariah. Jika dilihat dari tabeltabel dan pemaparan diatas, secara keseluruhan rata-rata responden menjawab setuju dan sangat setuju. Hal ini menggambarkan bahwasanya sejauh ini persepsi responden (nasabah) mengenai citra produk tabungan iB Plus dan BNI Syariah Card itu bersifat positif atau dapat dikatakan baik, karena responden yang menjawab ragu-ragu, tidak setuju dan sangat tidak setuju terbilang sedikit atau jarang. Dalam hal ini pihak bank harus lebih meningkatkan citra yang terbilang baik dan positif ini menjadi citra yang sangat baik dan sangat positif. 
Berdasarkan pengolahan data yang telah dilakukan, dapat diketahui nilai korelasi sebesar 0.583 hal ini menunjukkan adanya korelasi/hubungan yang sedang antara peningkatan citra produk tabungan iB Plus dan BNI Syariah Card (Y) dengan layanan e-banking (persepsi nasabah) (X). angka koefisien korelasi bertanda positif (+) menunjukkan bahwa hubungan antara kedua variabel terebut bersifat berbanding lurus, artinya peningkatan satu variabel akan diikuti oleh peningkatan variabel lain, sehingga semakin tinggi layanan e-banking (persepsi nasabah) akan membuat peningkatan citra produk tabungan iB Plus dan BNI Syariah Card meningkat juga. Kemudian korelasi variabel peningkatan citra produk tabungan iB Plus dan BNI Syariah Card(Y) dengan layanan e-banking (persepsi nasabah) (X) didapat angka probabilitas sebesar 0.000 atau probabilitas di bawah 0.05 $(0.000<0.05)$. dengan demikian $\mathrm{H}_{0}$ ditolak atau hal ini berarti memang ada hubungan antara peningkatan citra produk tabungan iB Plus dan BNI syaraiah Card(Y) dengan layanan e-banking (persepsi nasabah) (X). Dengan ini maka dapat disimpulkan bahwa nilai koefisien korelasi (R) sebesar 0.583 hal ini menunjukkan bahwa variabel layanan e-banking (persepsi nasabah) mempunyai hubungan dengan korelasi sedang.

Penelitian ini pada dasarnya dilakukan berdasarkan teori persepsi konsumen yang mana konsumen senantiasa mengembangkan inferensi atau kesimpulan mereka terhadap suatu obyek. Kesimpulan-kesimpulan menurut Nugroho J. Setiadi (2005) merupakan kepercayaan konsumen mengenai suatu obyek tersebut, dalam hal ini konsumen cenderung untuk membentuk citra terhadap suatu obyek yang didasarkan pada inferensi mereka. Dari teori tersebut, peneliti beranggapan bahwa konsumen akan menggunakan suatu obyek jika mereka sudah mempercayainya, dengan demikian mereka akan membentuk sendiri citra dari obyek tersebut berdasarkan dari inferensi (kesimpulan) yang mereka buat sendiri. Dalam hal ini, penulis menggambarkan obyek yang dimaksud adalah layanan e-banking dan produk tabungan iB Plus dan BNI Syariah Card, jika para nasabah telah mempercayai layanan e-banking pada tabungan iB Plus dan BNI Syariah Card, maka dengan sendirinya citra dari keduanya akan terbentuk. Dengan demikian 
asumsinya adalah jika tingkat kepercayaan nasabah terhadap layanan $e$ banking semakin meningkat, maka dengan sendirinya citra produk tabungan iB Plus dan BNI Syariah Card juga akan meningkat.

Ternyata asumsi peneliti tersebut adalah benar. Hasil penelitian yang peneliti lakukan pada nasabah pengguna e-banking pada tabungan iB Plus dan BNI syariah Card, membuktikan bahwa terdapat hubungan yang yang signifikan antara layanan e-banking menurut persepsi nasabah dengan peningkatan citra produk tabungan iB Plus dan BNI Syariah Card. Hal ini disebabkan karena hasil perhitungan dengan menggunakan analisis Product Moment Pearson diperoleh hasil nilai korelasi (rhitung) sebesar 0.583 lebih besar (rtabel) sebesar 0.148. Dengan demikian $\mathrm{H}_{0}$ ditolak dan $\mathrm{H}_{\mathrm{a}}$ diterima, artinya nasabah tabungan iB Plus dan BNI Syariah Card di BNI Syariah beranggapan bahwa ada hubungan antara layanan e-banking (persepsi nasabah) dengan peningkatan citra produk tabungan iB Plus dan BNI Syariah Card.

Semakin sering nasabah menggunakan layanan e-banking maka akan dengan sendirinya meningkatkan citra produk tabungan iB Plus dan BNI syariah Card, hal ini menunjukan bahwa seharusnya terdapat hubungan yang kuat bahkan sangat kuat terhadap keduanya. Tetapi dalam penelitian ini ternyata fenomena tersebut tidak sepenuhnya benar. Dari hasil penelitian yang peneliti lakukan ternyata hubungan antara layanan e-banking (persepsi nasabah) hanya 58,3\% yang berarti berukuran sedang. Hal tersebut terjadi mungkin peningkatan citra produk bukan hanya dipengaruhi dalam penggunaan layanan e-banking, tetapi juga dapat dipengaruhi oleh faktor lain, misalnya seperti kualitas pelayanan, kebutuhan, dan tingkat kepuasan. Sesuai dengan Setiadi (2005) yang mengemukakan peningkatan citra yang positif dapat dilakukan dengan cara meningkatkan kualitas pelayanan, memberikan apa yang di butuhkan oleh konsumen, dan menciptakan kepuasan di hati para konsumen. Jadi, dalam penelitian ini memang ditemukan adanya hubungan antara layanan e-banking (persepsi nasabah) terhadap peningkatan citra produk tabungan iB Plus dan BNI syariah Card.

Jika dikaitkan dengan teori, hal ini sesuai dengan konsep pemasaran inferensi perspektual. Nasabah mengembangkan inferensi atau kesimpulan 
mengenai merek, harga, kantor, dan perusahaan. Kesimpulan-kesimpulan itu merupakan kepercayaan mengenai suatu objek dari asosiasi masa lalu. Ada tiga tipe inferensi, yaitu (Setiadi, 2005): pertama, inferensi yang didasarkan pada evaluasi (evaluation based). Evalution based adalah penilaian yang menimbulkan evaluasi positif atau negatif secara konsisten pada suatu merek. Kedua, inferensi yang didasarkan pada kesamaan (similarity based). Similarity based adalah kepercayaan atas suatu objek yang didasarkan pada kesamaan dengan objek lain. Konsumen mengembangkan inferensi terhadap merek yang tidak diketahuinya dengan menghubungkan dengan merek yang telah dikenalnya. Ketiga, inferensi yang didasarkan pada korelasional (corelational based). Corelational based adalah inferensi korelasional yang di dasarkan pada asosiasi dari hal yang umum kepada hal yang spesifik.

Konsumen cenderung untuk membentuk citra produk terhadap merek dan perusahaan yang didasarkan pada inferensi mereka yang diperoleh dari stimulasi pemasaran dan lingkungan. Citra adalah total persepsi terhadap suatu objek, yang dibentuk dengan memproses informasi dari berbagai sumber setiap waktu. Sasaran penting dari strategi pemasaran adalah untuk mempengaruhi persepsi terhadap merek, toko, atau perusahaan. Jadi, pemasar harus secara konstan mencoba mempengaruhi citra konsumen.

Citra konsumen terdiri atas (Setiadi, 2005), yaitu: Pertama, Citra merek. Citra merek mempresentasikan keseluruhan persepsi terhadap merek dan dibentuk dari informasi dan pengalaman masa lalu terhadap merek itu. Kotler dan fox mendefinisikan citra sebagai jumlah dari gambaran-gambaran, kesankesan, dan keyakinan-keyakinan yang dimilki oleh seseorang terhadap objek. Citra terhadap merek berhubungan dengan sikap yang berupa keyakinan dan preferensi terhadap suatu merek. Konsumen dengan citra yang positif terhadap suatu merek, lebih memungkinkan untuk melakukan pembelian, oleh karena itu kegunaan utama dari iklan diantaranya adalah untuk membangun citra positif terhadap merek. Manfaat lain yang positif adalah perusahaan bisa mengembangkan lini produk dengan memanfaatkan citra positif yang telah terbentuk terhadap merek produk lama. Hal yang perlu diperhatikan adalah bagaimana mempertahankan dan meningkatkan citra merek yang sudah 
positif. Jika suatu saat perusahaan ingin mengubah merek produk yang telah lama ada dan mempunyai citra yang positif, maka perubahan itu harus terlebih dahulu menilai inferensi konsumen atas perubahan yang akan dilakukan.

Kedua, citra korporasi. Selain mengembangkan citra terhadap merek, konsumen juga memperhatikan berbagai informasi mengenai perusahaan atau korporasi, dan bagaimana pengalamannya atas penggunaan produk yang dihasilkan oleh perusahaan. Ketika konsumen mempunyai pengalaman yang baik atas penggunaan berbagai merek produk yang dihasilkan oleh sebuah perusahaan, maka konsumen akan mempunyai citra yang positif atas perusahaan tersebut. Pada saat itulah terbentuk apa yang disebut citra korporasi.

Citra adalah realitas, oleh karena itu jika komunikasi pasar tidak cocok dengan realitas, secara normal realitas akan menang. Komunikasi yang tidak didasarkan pada realitas hanya akan menciptakan harapan yang lebih tinggi daripada kenyataan yang dirasakan. Akibatnya, ketidakpuasan akan muncul dan akhirnya konsumen mempunyai persepsi yang buruk terhadap citra organisasi. Jika masalah citra adalah problem yang nyata, hanya tindakan nyata pula yang akan menolong. Masalah-masalah nyata yang berkaitan dengan kinerja organisasi yaitu kualitas teknis atau fungsional yang sebenarnya menyebabkan masalah citra. Tindakan internal yang memperbaiki kinerja organisasi dibutuhkan jika citra yang buruk ingin diperbaiki. Jika citra tidak diketahui, berarti terdapat masalah komunikasi.

Citra suatu produk, merek, dan perusahaan akhirnya akan menjadi baik, ketika konsumen mempunyai pengalaman yang cukup dengan realitas baru. Realitas baru yang dimaksud adalah bahwa sebenarnya organisasi atau sebuah perusahaan bekerja lebih efektif dan mempunyai kinerja yang baik terhadap konsumen.

\section{SIMPULAN}

E-banking memang diciptakan untuk memudahkan nasabah menikmati jasa-jasa layanan bank. Adapun operasionalisasi transaksi e-banking dilakukan dengan cara mengaktivasi terlebih dahulu rekening yang dimiliki nasabah, setelah itu pengguna fasilitas ini berhak melakukan transaksi melalui 
e-banking, seperti internet banking, mobile banking, dan SMS Banking. Ada beberapa kelebihan yang dapat diperoleh dari transaksi $e$-banking baik oleh pihak bank maupun pihak nasabah. Adapun kelebihan transaksi yang dapat di peroleh melalaui e-banking oleh pihak bank salah satunya adalah memudahkan bank dalam berinteraksi dengan nasbahnya melalui media electronic setiap saat. Sementara kelebihan transaksi yang dapat diperoleh melalui e-banking oleh pihak nasabah salah satunya adalah memperoleh kemudahan transaksi antara nasabah bank dengan nasabah lainnya.

Besarnya hubungan variabel Persepsi Nasabah terhadap variabel Peningkatan Citra Produk iB Plus dan BNI Syariah Card adalah 0,583 atau 58,3\%. Hal ini berarti bahwa hubungan antara variabel tingkat Persepsi Nasabah terhadap variabel Peningkatan Citra Produk iB Plus dan BNI Syariah Card adalah berukuran sedang.

Hasil olah data menunjukan bahwasanya pengguna layanan e-banking, rata-rata berkisar dari umur 20-30 tahun yang memiliki pekerjaan sebagai pegawai swasta, serta berpenghasilan 2 juta hingga 4 juta perbulan, kemudian kebanyakan dari mereka memiliki pendidikan terakhir di perguruan tinggi yang rata-ratanya lebih memilih menggunakan layanan SMS Banking ketimbang menggunakan layanan e-banking lainnya seperti internet banking, mobile banking, dan phone plus. Dan hasil olah data statistik deskriptif menunjukan bahwasanya persepsi nasabah mengenai layanan $e$ banking dan tabungan iB Plus dan BNI Syariah Card sejauh ini baik dan positif.

Penelitian yang dilakukan Herawaty dan Prayekti (2011), dimana tujuan penelitian ini adalah untuk mengetahui pengaruh dimensi internet banking service quality (IBSQ) yang meliputi online customer service quality, online system information quality, dan banking service product quality terhadap kepuasan nasabah internet banking. Selain itu juga untuk mengetahui pengaruh kepercayaan nasabah terhadap kepuasan nasabah internet banking. Variabel dalam penelitian ini Online Customer, Service Quality, Online System Information Quality, Banking Service Product Quality dan Kepercayaan Nasabah sebagai variabel independen. Sedangkan variabel dependennya adalah Kepuasan Nasabah. Untuk mendapatkan data dalam penelitian ini digunakan kuesioner. 
Populasi dalam penelitian ini adalah seluruh warga kota Yogyakarta pengguna internet banking. Teknik pengambilan sampel menggunakan convenience. Besarnya sampel 150 orang. Teknik analisa data secara deskriptif dan menggunakan regresi linier berganda. Hasil penelitian menunjukkan: terdapat pengaruh yang positif antara dimensi internet banking service quality (IBSQ) yang meliputi online customer service $\left(\mathrm{X}_{1}\right)$, online system information quality $\left(\mathrm{X}_{2}\right)$, dan banking service product quality $\left(\mathrm{X}_{3}\right)$ serta Kepercayaan nasabah $\left(\mathrm{X}_{4}\right)$ terhadap Kepuasan nasabah internet banking (Y). Hasil pengujian menggunakan uji t menunjukkan Online Customer Service Quality berpengaruh positif dan signifikan terhadap Kepuasan nasabah. Demikian halnya Online System Information Quality berpengaruh positif dan signifikan terhadap Kepuasan nasabah. Selain itu Banking Service Product Quality juga berpengaruh positif dan signifikan terhadap Kepuasan nasabah. Serta Kepercayaan pelanggan berpengaruh positif dan signifikan terhadap Kepuasan nasabah. Online nformation system quality merupakan variabel yang paling dominan pengaruhnya terhadap kepuasan nasabah. Selain itu menunjukkan tinggi rendahnya kepuasan nasabah internet banking 95,9\% ditentukan oleh dimensi internet banking service quality (IBSQ) yang meliputi online service quality, online information system quality, banking service product quality dan kepercayaan nasabah; sedangkan 4,1\% lainnya ditentukan oleh variabelvariabel di luar model penelitian ini.

Sakti (2012) melakukan penelitian yang bertujuan untuk mengetahui pengaru variabel e-banking yang terdiri dari kebebasan (Independence), kenyamanan (Convenience) dan keamanan (security) terhadap kepuasan nasabah bank BNI cabang Malang. Untuk mengetahui seberapa besar pengaruh variabel terikat (variabel e-banking) terhadap variabel bebas (kepuasan nasabah) digunakan analisis regresi dengan metode analisa uji t dan uji F. Penelitian ini termasuk dalam jenis penelitian Causal-Comparative Research, digunakan untuk menguji ada tidaknya hubungan sebab akibat dari kualitas pelayanan yang diberikan oleh layanan e-banking terhadap kepuasan nasabah. Sampel yang diambil sebesar 75 responden sedangkan pengambilan sampel menggunakan teknik sampling insidental, yaitu pengambilan sampel dengan 
menyebarkan kuesioner kepada nasabah bank BNI cabang Malang siapa saja yang secara kebetulan bertemu dengan peneliti. Dari hasil regresi dapat diketahui bahwa terdapat pengaruh yang signifikan antara variabel bebas (variabel e-banking) yaitu kebebasan (Independence), kesenangan (Convenience) dan keamanan (security) secara bersama-sama atau simultan terhadap variabel terikat yaitu kepuasan nasabah (Y), hal ini dapat dibuktikan dengan nilai $\mathrm{F}$ hitung $>\mathrm{F}$ tabel $(86,909>2,323)$ dengan signifikansi $<\alpha(0,000<0,05)$, dari hasil analisis uji t secara parsial dapat disimpulkan bahwa masing-masing variabel kebebasan (Independence), kenyamanan (Convenience) dan keamanan (security) secara parsial berpengaruh signifikan terhadap kepuasan nasabah dan juga dapat diketahui bahwa kenyamanan (Convenience) mempunyai pengaruh yang dominan terhadap kepuasan konsumen (Y), hal ini dapat dibuktikan dari besarnya nilai koefisien regresi variabel bebas yang mempunyai koefisien regresi paling besar $(0,488)$ adalah variabel kenyamanan (Convenience). Dengan demikian dapat dikatakan bahwa ketiga variabel bebas yang terdiri dari kebebasan (Independence), kesenangan (Convenience) dan keamanan (security) secara simultan dan parsial mempunyai pengaruh yang signifikan terhadap kepuasan nasabah bank BNI. Variabel kenyamanan (X2) merupakan variabel yang mempunyai pengaruh yang dominan terhadap kepuasan nasabah Bank BNI Cabang Malang.

Maharsi \& Fenny (2006) dalam penelitian yang bertujuan untuk mengetahui faktor-faktor yang mempengaruhi kepercayaan dan apakah kepercayaan mempengaruhi loyalitas pengguna terhadap internet banking di Surabaya. Sampel dalam penelitian ini berjumlah 106, yang merupakan pengguna internet banking dari bank BCA, Lippo, Mandiri, Niaga, BII, Permata, Bukopin dan Mega. Alat statistik yang digunakan adalah Structural Equation Modelling (SEM). Hasil dari penelitian ini mengindikasikan bahwa opportunistic behavior control merupakan faktor utama yang mempengaruhi kepercayaan nasabah terhadap internet banking, diikuti oleh shared value dan komunikasi, penelitian ini juga membuktikan bahwa kepercayaan berperan sebagai faktor yang mempengaruhi loyalitas pengguna internet banking.

Pinontoan (2013) Penelitian ini bertujuan untuk mengetahui pengaruh 
secara simultan dan parsial dari variabel E-Banking, Kualitas Pelayanan, Kualitas Komunikasi dan Kepercayaan terhadap Loyalitas Nasabah Pada PT. Bank Mandiri (Persero) Cabang Manado. Metode penelitian adalah asosiatif. Populasi penelitian adalah nasabah yang aktif berjumlah 28.662 orang. Pengambilan sampel secara purposive sampling . Dengan menggunakan rumus slovin maka jumlah sampel sebanyak 100 responden. Analisa menggunakan Regresi Berganda. Hasil penelitian menunjukan bahwa secara simultan dan parsial variabel E-Banking, Kualitas Pelayanan, Kualitas Komunikasi dan Kepercayaan berpengaruh terhadap Loyalitas Nasabah.

Lukitasari (2011) dalam penelitian menunjukkan bahwa produk perbankan yang menggunakan e-banking adalah produk pendanaan yaitu tabungan. Fasilitas e-banking sangat membantu dalam kinerja perbankan. Hal tersebut dapat dilihat pada pilihan nasabah, dimana seluruh nasabah menggunakan e-banking. Dari hasil penilaian, tiga indikator yaitu aspek tangible memberikan penilaian sangat tinggi sebesar 10\% dan tinggi sebanyak $75 \%$. Aspek reliability 72,5\% responden memberikan penilaian sangat tinggi sebesar 7,5\% dan tinggi sebanyak 65\%. Pada aspek competence 80\% responden memberikan penilaian sangat tinggi sebesar 10\% dan tinggi sebanyak $70 \%$. Sedangkan satu indikator yaitu pada aspek convenience 52,5\% responden memberikan penilaian cukup, dengan demikian dapat simpulkan bahwa dengan menggunakan e-banking kinerja produk pendanaan meningkat dibandingkan dengan yang tidak menggunakan teknologi e-banking.

Usnar (2012) dalam penelitian yang bertujuan untuk mengetahui kualitas layanan SMS Banking Bank BNI terhadap loyalitas nasabah di kota Makassar. Penelitian ini dilakukan dengan menyebarkan kuesioner pada 100 responden yang menggunakan layanan SMS Banking BNI di kota Makassar. Metode analisis data yang digunakan adalah regresi berganda. Hasil penelitian dalam penelitian ini menunjukkan pengaruh positif signifikan dimana jika terjadi kenaikan pada kualitas layanan SMS Banking, maka loyalitas nasabah juga akan meningkat. Variabel yang dominan mempengaruhi kepuasan nasabah adalah tangibles. 


\section{PUSTAKA ACUAN}

Andriani, R. 2009. Peran e-banking dalam pemasaran produk asuransi syariah pada PT.BNI Life Insurance Cabang Syariah.(Skripsi tidak dipublikasikan). Jakarta: Fakultas Syariah dan Hukum UIN Jakarta.

Ascarya. 2007. Akad \& Produk Bank Syariah. Jakarta: PT. RajaGrafindo Persada BNI Syariah, Profil Perusahaan, Booklet, Jakarta, BNI Syariah

Hansory, Anang, Pimpinan Bidang Operasional PT. BNI Syariah Cabang Jakarta Selatan, Wawancara Langsung.

Herawaty, J \& Prayekti. 2011. Pengaruh Dimensi Internet Banking Service Quality dan Kepercayaan Nasabah Terhadap Kepuasan Nasabah: Penelitian Empiris Terhadap Nasabah Internet Banking di Kota Yogyakarta. Akmenika UPY, Volume 8, 2011. Hlm 1 - 19.

Hoetomo. 2005. Kamus Lengkap Bahasa Indonesia. Surabaya: Mitra Pelajar.

Lathif, A.A. 2005. Fiqh Muamalat. Jakarta : UIN Press.

Lukitasari, F. 2011. Analisa E-Banking Dalam Meningkatkan Jasa dan Layanan Perbankan di BTN KCP Sukoharjo. (Tugas Akhir Tidak Dipublikasikan). Surakarta: Universitas Sebelas Maret.

Maharsi, S \& Fenny. 2006. Analisa Faktor-faktor Yang Mempengaruhi Kepercayaan dan Pengaruh Kepercayaan Terhadap Loyalitas Pengguna Internet Banking di Surabaya. Jurnal Akuntansi dan Keuangan, Vol. 8, No. 1, Mei 2006. Hlm $35-51$

Nugroho, A.B. 2005. Strategi Jitu Memilih Metode Statistik Penelitian Dengan SPSS, Yogyakarta: ANDI.

Perwataatmadja, K \& M.S. 1997. Apa dan Bagaimana Bank Islam. Yogyakarta: PT. Dana Bhakta Wakaf.

Pinontoan, W. 2013. Pengaruh E-banking, Kualitas Pelayanan, Kualitas Komunikasi dan Kepercayaan Terhadap Loyalitas Nasabah Pada PT Bank Mandiri cabang Manado. Jurnal Riset Ekonomi, Manajemen, Bisnis, dan Akuntansi, Vol. 1, No. 4, Desember 2013. Hlm. 192-201.

Rochaety, Eti, dkk. 2007. Metodologi Penelitian Bisnis: Dengan Aplikasi SPSS. Jakarta: Penerbit Mitra Wacana Media.

Sakti, C.P. 2012. Pengaruh Fasilitas E-banking Terhadap Peningkat Kepuasan 
Nasabah: Studi Pada Bank BNI Cabang Malang. (Tesis Tidak Dipublikasikan). Malang: Universitas Brawijaya.

Setiadi, N.J. 2005. Perilaku Konsumen Konsep dan Implikasi untuk Strategi penelitian Pemasaran. Jakarta: Prenada Media.

Simamora, B. 2002. Panduan Riset Perilaku Konsumen. Jakarta : PT Gramedia Pustaka Utama.

Soeratno \& L.Arsyad. 2003. Metodologi Penelitian Untuk Ekonomi Dan Bisnis Edisi Revisi. Yogyakarta : UPP AMP YKPN

Subhan, M.,et.al. 2001. Dasar-Dasar Penelitian Ilmiah. Bandung: Pustaka setia.

Sugiyono. 2009. Metode Penelitian Bisnis: Pendekatan Kuantitatif, Kualitatif, dan R\&D. Bandung: Alfabeta.

Sujianto, E.A. 2009. Aplikasi Statistik dengan SPSS 16.0. Jakarta: PT. Prestasi Pustakaraya

Usnar, N. D. 2012. Analisis Pengaruh Kualitas Layanan SMS Banking Bank BNI Terhadap Loyalitas Nasabah di Kota Makasar. (Skripsi Tidak Dipublikasikan). Makasar: Universitas Hasanudin.

Zakiyah, C, Customer Sevices PT. BNI Syariah Cabang Jakarta Selatan, wawancara Langsung. 